\title{
Az MTA Regionális Tudományi Bizottságának programja a 2012-2014 közötti időszakra
}

\section{Programme of HAS Committee on Regional Studies between 2012-2014}

\author{
HORVÁTH GYULA
}

I. Az 1986-ban alapított Regionális Tudományi Bizottság az MTA elismerten jól működő tudományos testülete. Az MTA Alapszabálya szerint a bizottság feladata a következőkre terjed ki:

a) figyelemmel kíséri az általa gondozott tudományág fejlődését és hazai helyzetét;

b) tudományos üléseket szervez;

c) állást foglal és véleményt nyilvánít a tudományág körébe tartozó vagy a tudományág szempontjából jelentős tudományos, tudománypolitikai, kutatásszervezési és személyi kérdésekben;

d) a szakterület nevében javaslatot tesz a tudományos osztály könyv- és folyóirat-kiadási tervére;

e) részt vesz az MTA doktora cím odaítélésére indult eljárásokban, nyilatkozik a kérelmező habitusáról, a doktori eljárásban az Alapszabály szerinti véleményezési jogkört gyakorolja, ezáltal segíti a tudományos osztályt javaslatának kialakításában.

A bizottság eddigi müködésében e feladatok értelemszerüen változó súllyal szerepeltek, ám hosszabb időszakokat tekintve a tematikai paletta kiegyensúlyozott volt. Ez a megállapítás különösen a doktori eljárásból adódó feladat esetében tekinthető igaznak. A doktori cselekmény elindítása egyéni kutatói döntésen nyugszik, a bizottságnak e tekintetben érdemleges befolyása nincsen.

II. A regionális tudomány nemzetközi és hazai környezetében zajló változások arra hívják fel a figyelmet, hogy e tudományág jövőjének megtervezése érdekében számos kérdést célszerü napirendre tűzni.

- A nemzetközi regionális tudományban intenzív gyarapodás tapasztalható, új kutatási irányok fogalmazódnak meg, nő a tudományos orgánumok száma, emelkedik a kutatói létszám.

- A környező országok regionális tudományi mühelyei az intézményesülés szakaszába léptek, egyetemi tanszékek specializálódnak a területfejlesz-

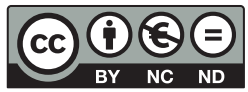


tés különböző elemeinek a kutatására és oktatására, folyóiratok jelentek meg, érezhetően bővültek a nemzetközi tudományos munkamegosztásba való bekapcsolódás formális jellemzői is.

- Magyarországon a nemzetközi folyamatoktól eltérően alakul a regionális tudomány helyzete. A Regionális Kutatások Központja az akadémia kutatóhálózatának átalakítása során elveszítette önállóságát, humán erőforrásai jelentősen csökkentek. A felsőoktatásban zajló változások és forráskivonás miatt a korábban jelentős eredménynek tartott regionális és környezeti gazdaságtani mesterprogramok a közgazdászképzésben összezsugorodtak, ami néhány év múlva a doktori iskolákban eredményez kedvezőtlen változásokat. A regionális tudomány eredményei iránt - más tudományágazatokéhoz hasonlóan - csökkent a felhasználói kereslet, ez a kutatási források szűkülését idézte elő.

III. A tudományágazatra hatást gyakorló tényezők sokoldalú ismeretére van szükség. A bizottság ezért az egyes elemeket különböző formában és fórumokon tüzi napirendre.

1. A regionális tudomány helyzete a világban és Magyarországon. A regionális tudomány kutatási irányai, szervezetei, eredményeinek felhasználása. A tudományágazat helyzetének értékelése jelenti a fejlődési stratégia kiindulópontját. E témakört a Magyar Regionális Tudományi Társasággal közösen érdemes megvitatni.

A nemzetközi regionális tudomány jeles képviselőinek ismertsége magyar társadalomtudományi körökben nem tekinthető megfelelőnek. Tudományos üléssorozatot kell szervezni a tudomány nagy egyéniségeinek pályafutásáról, tudományos eredményeiről, az előadásokat publikálni kell.

A bizottsági diszciplínához kapcsolódóan a IX. osztálynak egy külső (Benedek József) és egy tiszteleti (Antoine S. Bailly) tagja van. Törekedni kell arra, hogy a kiemelkedő kutatók köréből a külső és tiszteleti tagok száma gyarapodjon.

2. A regionális tudomány tudomány-rendszertani helye. Ma Magyarországon a regionális tudomány a különböző K+F-tevékenységek (pályázatok, képzési programok stb.) során alkalmazott tudományágazati listákon csak ritkán jelenik meg. Nyugat-Európában és az Egyesült Államokban a „regional science" a tudományrendszertanban több évtizede szerepel, tudományos testületi, értékelési, pályázati formációk kapcsolódnak hozzá. Célszerü javaslatot tenni a magyar tudományrendszertan gondozásában illetékes szervezetnek e tudományágazat pozicionálására.

3. A magyar regionális tudomány nemzetközi pozíciói. Eredményeink nemzetközi elismertségét, a külföldi folyóiratokban való publikálás lehetőségeit, a konferenciaszerepléseket az itthon művelt témák korszerűsége, a nemzetközi kutatási irányokhoz való kapcsolódás és a nemzetközi tudományos munkamegosztásban elfoglalt pozíciók határozzák meg. Áttekintésre érdemes a magyar regionális tudomány nemzetközi együtt- 
működési hálózata, az európai uniós társadalomtudományi kutatások regionális elemeinek várható orientációja a 2020-ig terjedő időszakban, különös tekintettel az új keretprogramokra. A kiemelt tudományos rendezvényeket is ebben a gondolatkörben ajánlatos megtervezni.

4. Publikálási lehetöségek itthon és külföldön. A tudományágazat hazai folyóiratai, könyvsorozatai, eseti kiadványai, konferenciakötetei viszonylag széles kínálatot mutatnak. Érdemesnek tűnik az orgánumok közötti együttmúködés kialakítása, ennek alapját a különböző publikációs fórumok stratégáinak ismerete jelenti. Ajánlatos megvizsgálni a magyar regionális kutatók nemzetközi publikációs szereplését, illetve választ keresni arra a kérdésre, mi lenne a megfelelő formája egy, a magyar regionális kutatási eredményeket rendszeresen közlő, hazai megjelenésű, angol nyelvű kiadványnak.

5. A regionális tudomány megismertetése a közvéleménnyel. Az utóbbi évek kedvezőtlen jelenségeinek okai között a regionális tudományról alkotott felszínes kép, az alapos ismeretek hiánya is fellelhető. Fontos feladatnak tekinthető a tudományágazat eredményeinek, a felhasználás lehetőségeinek, a kutatói közösségek működésének megismertetése a szélesebb szakmai közönséggel, illetve a tágabb közvéleménnyel. Ehhez aktív sajtókapcsolatokra, figyelemfelkeltő rendezvényekre van szükség. A szakmai körök számára fontos az internetes megjelenés és a jól bevált Hírlevél. E feladatokat a Magyar Regionális Tudományi Társasággal közösen célszerü végezni.

6. Regionális tudományi enciklopédia. Egy tudományágazat elméleti tételeinek, fogalmi rendszerének, eredményeinek összegző gyüjteménye erősíti pozícióit, fejleszti kapcsolatait a társtudományokkal. A magyar regionális tudomány felhalmozott tudásanyagát szintetizáló enciklopédia összeállítása a regionális tudományi mühelyek együttmüködésének fontos motiváló ereje lehet. A kudarccal végződött korábbi kísérletek tanulságai alapján arra a következtetésre kell jutnunk, hogy az enciklopédiának szakmai egyetértésen nyugvó megállapításokat kell tartalmaznia. Tudományágazatunk számos alapkérdését nyílt szakmai fórumokon kell megvitatnunk. A vitairatok összeállítása és a viták megszervezése az albizottságok feladata legyen (ezáltal az albizottságok aktivitása is folyamatos lehet).

7. A köztestületi tagok számának gyarapitása. A bizottsághoz sorolt köztestületi tagok száma megközelíti a százat. Létszámát tekintve a IX. osztály tíz bizottsága között a hatodik helyet foglalja el. Számos, fokozattal rendelkező regionális szakember nem tagja a köztestületnek. Őket fel kell kérni a belépésre, illetve szakmai támogatást kell nyújtani ahhoz, hogy publikációik felkerüljenek az MTMT-re. A regionális tudomány és a kapcsolódó tudományterületek doktori iskoláiban fokozatot szerzett hallgatókra különös figyelmet kell fordítani. Mivel a határon túli magyar regionális tudománynak szép számmal vannak minősített kutatói a regionális tudományterületen - egy részük külső köztestületi tag -, az ő részvételük szervezése külön feladatot jelent. 
8. A doktoráltatási jogosítványok gyakorlása. A bizottság doktori követelményrendszerét nyilvánosságra kell hozni, a bizottsági rendezvények, közszereplések szervezésében a doktori cselekményt kezdeményezőkre külön figyelmet kell fordítani.

9. A hazai tudományos kapcsolatrendszer alakítása. A bizottság stratégiai partnere a Magyar Regionális Tudományi Társaság. A két szervezet közötti munkamegosztást rögzíteni célszerü. Fontos együttműködő partnernek tekintendők a területi akadémiai bizottságok területfejlesztési munkabizottságai. Érdemi kapcsolatot kell tartani azokkal a tudományos szervezetekkel, amelyek statútumában szerepel a területi összefüggések bizonyos részterületeinek az elemzése (pl. MTA Társadalom-földrajzi Bizottsága, Magyar Statisztikai Társaság Területi Statisztikai Szakosztálya stb.). A bizottság megkülönböztett figyelemmel kíséri a regionális tudományi doktori iskolák működését, tevékenységük támogatására külön munkabizottságot szervez.

$$
* * *
$$

A Regionális Tudományi Bizottság e programpontok megvalósításától azt reméli, hogy a magyar regionális tudomány nemzetközi versenyképessége erősödik, a tudományágazat a hazai tudományosság ismert és elismert szereplője lesz, a regionális kutatók kvalifikációja minőségében is erőteljesen fejlődik, és a tudományágazat eredményeinek hasznosítása elősegíti Magyarország előrehaladását. Tevékenységével a bizottság erősíteni kívánja a szakma belső kohézióját éppúgy, mint a lényeges szempontokra kiterjedő, nyílt tudományos vitaszellemet.

A programot a Regionális Tudományi Bizottság 2012. március 21-i ülésén elfogadta.

1. melléklet: A Regionális Tudományi Bizottság tisztségviselői és albizottságai

Elnök: Horváth Gyula DSc, alelnök: Nemes Nagy József DSc, Szirmai Viktória, DSc, titkár: Somlyódyné Pfeil Edit PhD

\begin{tabular}{|c|c|c|}
\hline Albizottság & Elnök & Titkár \\
\hline $\begin{array}{c}\text { Innovációs-technológiai } \\
\text { és hálózatkutatási }\end{array}$ & Varga Attila DSc & Sebestyén Tamás PhD \\
\hline Képzési & Lengyel Imre DSc & Káposzta József PhD \\
\hline Régiótörténeti & Baranyi Béla DSc & Benkő Péter CSc \\
\hline $\begin{array}{l}\text { Térségi társadalmi } \\
\text { egyenlőtlenségek }\end{array}$ & Szirmai Viktória DSc & Izsák Éva PhD \\
\hline Kutatás-módszertani & Nemes Nagy József DSc & Dusek Tamás PhD \\
\hline $\begin{array}{c}\text { Területi kormányzás és } \\
\text { menedzsment }\end{array}$ & Pálné Kovács llona DSc & Perger Éva CSc \\
\hline
\end{tabular}




\section{Horváth Gyula}

2. melléklet: A Regionális Tudományi Bizottság taglétszáma, 2012. május

\begin{tabular}{lc}
\hline Tudományos fokozat & Létszám, fö \\
\hline Kandidátus & 17 \\
PhD & 66 \\
MTA doktora & 14 \\
MTA rendes tagja & 1 \\
MTA külső tagja & 1 \\
\hline Összesen & 99 \\
\hline
\end{tabular}

